\title{
Declaración sobre la promoción de la reducción del consumo de sodio en los alimentos procesados en Argentina
}

\author{
Statment about promoting reduction of sodium intake in processed foods in Argentina
}

\begin{abstract}
Instituciones adherentes: Fundación Interamericana del Corazón-Argentina (FIC Argentina), Fundación Cardiológica Argentina (FCA), Sociedad Argentina de Hipertensión Arterial (SAHA), Sociedad Argentina de Cardiología (SAC), Fundación Cardio, Federación Argentina de Cardiología (FAC), Sociedad Interamericana de Cardiología (SIAC), Escuela de Nutrición de la Universidad Maimónides, Instituto Universitario CEMIC (IUC), Programa PROCORDIS de la Fundación Bioquímica Argentina, Programa Saludable para el Tratamiento de la Obesidad del Hospital Italiano de Buenos Aires (PROSAHI), Federación Nacional de Operadores de Mercados Fruti hortícolas de la República Argentina (FENAOMFRA), Federación Argentina de Medicina Familiar y General (FAMFyG), Programa de Prevención del Infarto en Argentina (PROPIA), Servicio de Medicina Familiar y Comunitaria del Hospital Italiano de Buenos Aires, Consumidores Argentinos Centro de Estudios Sobre Nutrición Infantil (CESNI), Acción del Consumidor (ADELCO), Programa de Desarrollo de Alimentos, Nutrición y Salud de la Universidad Nacional de La Plata (ProDANyS), Departamento de Salud Pública del Instituto Universitario Hospital Italiano de Buenos Aires, Facultad de Bromatología de la Universidad Nacional de Entre Ríos.
\end{abstract}

\section{Resumen}

Representantes de 22 organizaciones de la Sociedad Civil se reunieron en la Ciudad Autónoma de Buenos Aires el 21 de noviembre de 2012, en el contexto de la jornada "Reducción de sodio en los alimentos procesados y su impacto en la salud pública: el rol de la sociedad civil", con el objetivo de debatir y reflexionar respecto el rol de la sociedad civil en la problemática del excesivo consumo de sal en Argentina. El evento contó con la presencia de la Lic. Elizabeth Dunford, investigadora de The George Institute de Australia, quien lidera una iniciativa global de evaluación de la composición de alimentos procesados y ofreció una conferencia sobre las políticas desarrolladas en distintos países y sus resultados. En Argentina, un acuerdo voluntario firmado en 2011 entre el Ministerio de Salud de la Nación y 50 empresas de la industria alimenticia propuso reducir el contenido de sodio en determinados alimentos procesados, aunque aún no se cuenta con datos concretos acerca de su implementación.

Al finalizar el encuentro, representantes de las organizaciones participantes consensuaron una declaración conjunta en la que se comprometieron a avanzar tanto en la difusión de información sobre el daño del consumo excesivo de sal, como en la promoción de políticas públicas efectivas que contribuyan a la protección de la salud de la población. A continuación se reproduce el texto completo de la misma y las instituciones que la suscriben.

\section{Abstract}

Representatives of 22 civil society organizations gathered in the Autonomous City of Buenos Aires on November 21, 2012 , in the context of the lecture "Reducing sodium in processed foods and their impact on public health: the role of civil society ", in order to discuss and think about the role of civil society in the problem of excessive salt consumption in Argentina. Lic. Elizabeth Dunford (a researcher at The George Institute of Australia) who is leading a comprehensive evaluation of the composition of processed foods attended the event and gave a lecture about the policies developed in different countries and their results. In Argentina, a voluntary agreement signed in 2011 between the Ministry of Health of the Nation and 50 companies from the food industry proposed to reduce the sodium content of processed foods in particular, although there is no specific data on its implementation.

After the meeting, representatives of the participating organizations agreed on a joint statement in which they pledged to advance on both the dissemination of information about the harm of excessive salt consumption, and in the promotion of effective public policies that contribute to the protection of the health of the population. The following is the full text of the statement and the institutions that subscribed it.

\section{Declaración}

Las organizaciones y las personas comprometidas con la vida y la salud pública, en el marco del evento "Reducción de sodio en los alimentos procesados y su impacto en la salud pública: el rol de la sociedad civil" declaran lo siguiente:

Considerando que en la actualidad las enfermedades cardiovasculares son la primera causa de muerte y que representan un $30 \%$ de todas las muertes registradas en el mundo; recordando que la hipertensión arterial aumenta la probabilidad de presentar accidente vascular encefálico, cardiopatía coronaria, insuficiencia cardíaca congestiva, insuficiencia renal crónica, y que en Argentina una de cada cuatro personas es hipertensa; subrayando que está ampliamente demostrado que el consumo de sal está fuertemente asociado con los niveles de presión arterial; observando que en nuestro continente la tendencia del sobreconsumo de sal se repite con una ingesta estimada de 11,5 g/persona/día y, en Argentina, de acuerdo a los datos estimados por el Ministerio de Salud de la Nación, cerca de $12 \mathrm{~g} /$ día, de los cuales el $70 \%$ proviene de los alimentos procesados; afirmando que la Organización Mundial de la Salud (OMS) recomienda reducir el consumo de sal, en el caso de los adultos a $5 \mathrm{~g}$ por día, equivalentes a $2000 \mathrm{mg}$ de sodio; señalando que al reducir su consumo se observa una disminución en los valores de presión arterial sistólica, tanto en pacientes hipertensos como en normotensos y una disminución del riesgo de enfermedades cardiovasculares y la morbi-mortalidad causada por ellas; sosteniendo que la reducción de sal es una de las estrategias más costoefectivas para prevenir enfermedades crónicas no transmisibles (ECNT) y que benefician a toda la población y no sólo a los hipertensos; señalando que, según estimaciones del Ministerio de Salud de la Nación, la disminución de $3 \mathrm{~g}$ de la ingesta diaria de sal por persona evitaría en nuestro país cerca de 6000 muertes por enfermedad cardiovascular y ataques cerebrales, y aproximadamente 60.000 eventos cada año, lo cual equivaldría a una reducción significativa en costos de salud; y reconociendo que es responsabilidad del Estado garantizar las medidas necesarias para reducir el consumo de sal y, de ese modo, garantizar el derecho a la salud de toda la población, las organizaciones abajo firmantes nos comprometemos a contribuir a la protección de la salud de los habitantes de nuestro país a través de las siguientes acciones:

- Alentar la colaboración entre las organizaciones de la sociedad civil para intercambiar experiencias y propiciar espacios de trabajo conjunto.

- Concientizar a la población acerca del daño que provoca el consumo excesivo de sal y difundir información para prevenirlo.

- Promover políticas de salud pública efectivas para reducir el consumo de sal a nivel poblacional. 